ISSN 0258-7122

Bangladesh J. Agril. Res. 39(4): 661-673, December 2014

\title{
STUDY ON DRYING KINETICS OF SUMMER ONION
}

\author{
MD. MASUd ALAM ${ }^{1}$, MD. NURUL ISLAM ${ }^{2}$ AND MD. NAZRUL ISLAM ${ }^{2}$
}

\begin{abstract}
The present study was concerned with the kinetics of drying of summer onion. Drying was done in a mechanical dryer at constant air flow using blanched and unblanched onion with variable temperature $\left(52,60\right.$ and $\left.68^{\circ} \mathrm{C}\right)$ and thickness $(3$, 5 and $7 \mathrm{~mm}$ ). Drying rate was increased with increase of temperature and decreased with the increase in thickness in blanched and unblanched onion. Blanched onion showed higher drying rate than unblanched onion. Drying rate constant and thickness can be expressed as power low equations. The value of index " $n$ " were found to be 1.277 and 0.845 for onion indicating that the external resistance to mass transfer was highly significant. The effect of temperature on diffusion co-efficient follows an Arrhenius type relationship. The activation energy $\left(E_{a}\right)$ for diffusion of water was found $5.781 \mathrm{Kcal} / \mathrm{g}$-mole for unblanched and $2.46 \mathrm{Kcal} / \mathrm{g}$-mole for blanched onion when onions were dried in mechanical dryer.
\end{abstract}

Keywords: Onion, drying rate constant, diffusion coefficient, activation energy.

\section{Introduction}

In Bangladesh onion is mainly used as major spices and occasionally used as salad to increase the palatability of food. It is used in various ways in all curries, fried or baked. It is also used in processed from eg. flakes, powder, paste, crush and pickles. In developed countries such as USA, Japan etc. about $45 \%$ of entire output of fresh onion is dehydrated and sold to the food processors for use in salad, tomato products, biryani and in several food preparation.

Normally onion is cultivated during the Winter season in Bangladesh. But from 2001-02 it is also grown in summer season. There are three varieties of Bangladesh Agricultural Research Institute (BARI) known as BARI-2, BARI-3 and BARI-5 which are growing in summer season and their yield is 4-5 times more than winter onion. But their keeping quality is very poor.

Among the spices grown in Bangladesh, onion ranks second in acreage and first in production (BBS, 2007). More than 8.9 lakh mt. of onions are produced from about 1.28 lakh hectare area (BBS, 2007). The imported cost of onion in 2009-10 was about 1516 crore taka (Bangladesh Bank).

${ }^{1}$ Senior Scientific Officer, Spices Research Center, Bangladesh Agricultural Research Institute (BARI), Bogra. ${ }^{2}$ Professor, Department of Food Technology and Rural Industries, Bangladesh Agricultural University (BAU), Mymansingh, Bangladesh. 
Onions are available in large quantity during the harvesting season. Most of them are not utilized properly due to over supply in peak season, lack of adequate processing technology, preservation, adequate transportation and marketing facilities. As a result about 40-50 percent post-harvest losses are observed in winter onion during storage (BARI, 2010). Even the summer onion can not be kept more than 15-30 days. The losses include decay or rotting, sprouting, physiological loss of weight, splitting of bulbs, discoloration, shrinkage, descaling and rooting.

Onion contains little amount of vitamin ' $\mathrm{B}$ ' and ' $\mathrm{C}$ ' and trace of iron and calcium. Besides, it has got manifold medicinal values also (Arya, 2003).

Proper drying techniques as well as proper slice thickness of product are required for obtaining good quality dried products. Drying can be accomplished in a mechanical dryer, direct sunlight or solar dryer. In the mechanical dryer, desired temperature and airflow could be maintained. Compared to sun/solar drying higher airflow and temperature can be used in mechanical drying. This leads to high production rates and improved quality products due to shorter drying time and reduction of the risk of insect infestation and microbial spoilage. Since mechanical drying is not dependent on sunlight so it can be done as when necessary.

Several drying system available in the literature for explaining thin layer drying characteristics of fruits and vegetables have been used by Yoo (1988), Sharma et al. (2005), Kumar et al. (2004), and Lopez et al (1995) for onion and Telis et al. (2003) for tomato.

On the basis of the information so far accumulated, the present work has been undertaken to study the drying behavior of summer onion slices using Cabinet drying system and to examine the effect of slice thickness of onion and temperature on different drying parameter.

\section{Materials and Method}

The study was conducted in the laboratory of the Department of Food Technology and Rural Industries, under the Faculty of Agricultural Engineering and Technology, Bangladesh Agricultural University, Mymensingh.

\section{Materials required}

Fresh summer onion were collected from the Spices Research Center of BARI for conducting the laboratory study. Cabinet dryer (model OV-165 Gallenkamp Company) was used for the dehydration of summer onion. The dryer consists of several chambers in which trays of sample was dried. The velocity of air was recorded $(0.6 \mathrm{~m} / \mathrm{s})$ by an Anemometer. 


\section{Mechanical drying of onion slices}

For determining the effect of the temperature and the thickness on the rate of the drying onion were peeled and sliced by a slicer and samples were taken for the determination of moisture content. In some cases the onion slices were blanched in steam for five minutes using perforated wire pot. Fresh onion slices $(3,5$ and 7 $\mathrm{mm}$ thick) were placed in trays in single layer and drying commenced in the dryer at constant air velocity $(0.6 \mathrm{~m} / \mathrm{sec})$ and at a specified air dry bulb temperature $\left(52,62\right.$ or $\left.68^{\circ} \mathrm{C}\right)$. Moisture content at each time interval was determined gravimetrically on the basis of initial moisture content and weight loss was used as a measure of the extent of drying.

Ficks second law of diffusion is applied to describe mass transfer during drying since food dehydration is assumed to be a diffusion process. The expression is:

$$
\frac{\delta M}{\delta t}=\Delta^{2} D_{e} M--------------------------(1)
$$

Where,

$$
\begin{aligned}
& \mathrm{M}=\text { Moisture content }(\text { dry basis }), T=\text { Time and } \\
& D_{e}=\text { Effective diffusion co-efficient }\left(\mathrm{cm}^{2} / \mathrm{sec}\right)
\end{aligned}
$$

To find a solution of the above unsteady state diffusion equation for one dimensional transport for the case of initial uniform moisture distribution in the sample and negligible external resistance, appropriate boundary conditions are assumed. The solution for an infinite slab (with thickness, 1 ), when dried from one major face (Brooker et al., 1974; Islam, 1980 and Crank, 1975) is:

$$
M R=\frac{M_{t}-M_{e}}{M_{o}-M_{e}}=\frac{8}{\pi^{2}} \sum_{n=0}^{\alpha} \frac{1}{(2 n+1)^{2}} \operatorname{Exp} \frac{-(2 n+1)^{2} \pi^{2} D_{e} t}{L^{2}}------(2)
$$

Where,

$\mathrm{MR}=$ Moisture ratio

$\mathrm{M}_{\mathrm{t}}=$ Moisture content at the time $\mathrm{t}$

$\mathrm{M}_{\mathrm{o}}=$ Initial moisture content

$\mathrm{M}_{\mathrm{e}}=$ Equilibrium moisture content respectively.

For low $\mathrm{M}_{\mathrm{e}}$ values and for moisture ratio, $\mathrm{MR}<0.6$ equation (2) reduces to:

$$
M R=\frac{M_{t}}{M_{o}}=\frac{8}{\pi^{2}} e^{\pi^{2} D_{e} t / L^{2}}=\frac{8}{\pi^{2}} e^{-m t} \text { or } \ln M R=\ln \frac{8}{\pi^{2}}-m t---(3)
$$


Where, $\mathrm{m}=\frac{\pi^{2} D_{e}}{L^{2}}=$ drying rate constant, $\sec ^{-1}$

Consequently, a straight line should be obtained when plotting $L_{n} M R$ versus time $(t)$. The slope of the regression line is the drying rate constant, $m$ for which the effective diffusion co-efficient, $\mathrm{D}_{\mathrm{e}}$ is calculated.

The diffusion co-efficient, $D_{e}$ has an Arrhenius type of relationship with drying air dry bulb temperature (abs). The relationship is as follows (Heldman, 1974).

$$
\begin{gathered}
\frac{d \operatorname{In} D_{e}}{d T_{a b s}}=\frac{E_{a}}{R T_{a b s}} \\
O r, \ln D_{e}=\ln D_{0}-\frac{E_{a}}{R T_{a b s}}--------------------(5)
\end{gathered}
$$

Where, $D_{o}$ is constant of integration and usually referred to as a frequency factor when discussing Arrhenius equation, $\mathrm{E}_{\mathrm{a}}$ is the activation energy of diffusion of water $\mathrm{Kcal} / \mathrm{g}$-mole, $\mathrm{R}$ is the universal gas constant $1.98 \mathrm{cal} / \mathrm{g}-\mathrm{mol},{ }^{0} \mathrm{~K}$ and $\mathrm{T}_{\mathrm{abs}}$ is the absolute temperature, ${ }^{\circ} \mathrm{k}$.

From equation (5), it is apparent that plotting diffusion co-efficient $\left(D_{e}\right)$ versus the inverse absolute temperature on semi-logarithmic co-ordinates would lead to the evaluation of activation energy for diffusion of moisture during drying and activation energy was calculated by non-linear regression analysis.

From the semi-theoretical equation as shown in equation (3), it may be noted that the drying rate constant, $\mathrm{m}$ is a function of the square of thickness of the product being dehydrated, as seen in equation 4, Symbolically, this may represented as:

$\mathrm{m}=\mathrm{A}(\mathrm{L})^{-\mathrm{n}}$

Or $\log (\mathrm{m})=\log \mathrm{A}-\mathrm{n} \log (\mathrm{L})$

Where, $A=\pi^{2} D_{e}, \quad n=2$

The above relationship shows that if external resistance to mass transfer is negligible and if simultaneous heat and mass transfer effects are taken into account, the value of the exponent of the power law equation should be 2 . But the above conditions are not always satisfied and experimentally determined ' $n$ ' value is found to be less than 2 (Islam, 1980).

\section{Results and discussion}

The effect of thickness and temperature on drying time for blanched and unblanched onion were observed.Diffusion co-efficient and activation energy for 
different temperature and thickness dependency of drying rate constant were also investigated with respect to blanched and unblanched summer onion in mechanical dryer.

The effect of thickness 3,5 and $7 \mathrm{~mm}$ of onion slices on drying rate were observed at constant temperature, airflows and relative humidity. Another experiment was conducted by using $5 \mathrm{~mm}$ thick onion slices at three different air dry bulb $(\mathrm{db})$ temperatures such as 52,62 and $68^{\circ} \mathrm{C}$ to investigate the effect temperature on drying rate. The effect of blanching on drying rate was also investigated with respect to different thickness and temperature in mechanical drying.

\section{Effect of thickness on drying behaviour of unbalanced and blanched onion slice}

To determine the influence of thickness on drying behavior 3, 5 and $7 \mathrm{~mm}$ slices (without blanching) were dried at a constant air dry bulb temperature $\left(60^{\circ} \mathrm{C}\right)$ and at constant air velocity in a cabinet dryer. The results were analyzed by using equation (3) and moisture ratio (MR) versus drying time (hr) was plotted on a semi-log graph paper and regression lines were drawn (Fig.1). For the three different thickness of samples, the following regression equations were developed:

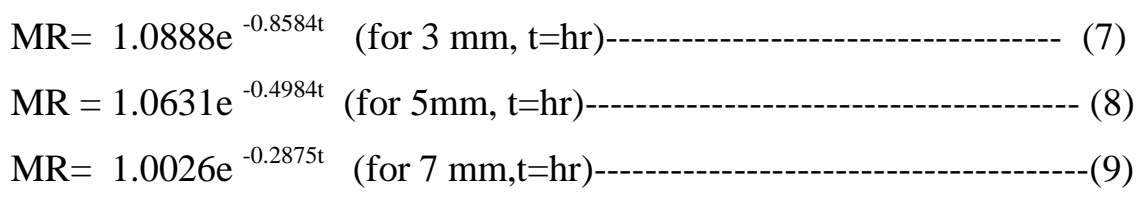

The effect of different slice thicknesses on drying time is shown in Fig.1 for onion. The drying process took place in the falling rate period and no constant rate period was observed from the drying curves. From Fig.1, it was also observed that thickness had profound influence on drying time and as the thickness of the samples increased, the drying time to a specific moisture ratio also increased with resultant decrease in drying rate constant. It was also noticed that for a specific moisture ratio ( $\mathrm{MR}=0.1) 3 \mathrm{~mm}$ thick slice required the least time $(3.78 \mathrm{hr})$, followed by $5 \mathrm{~mm}$ thick slice $(4.7 \mathrm{hr})$, while the highest time $(8.0$ hr) was required to dry $7 \mathrm{~mm}$ thick onion slice. From the developed equations (7 to 9), it is clearly seen that the rate constant decreased with the increased in slice thickness. The decrease in rate constant, however, does not maintain linear proportionality with slice thickness. 


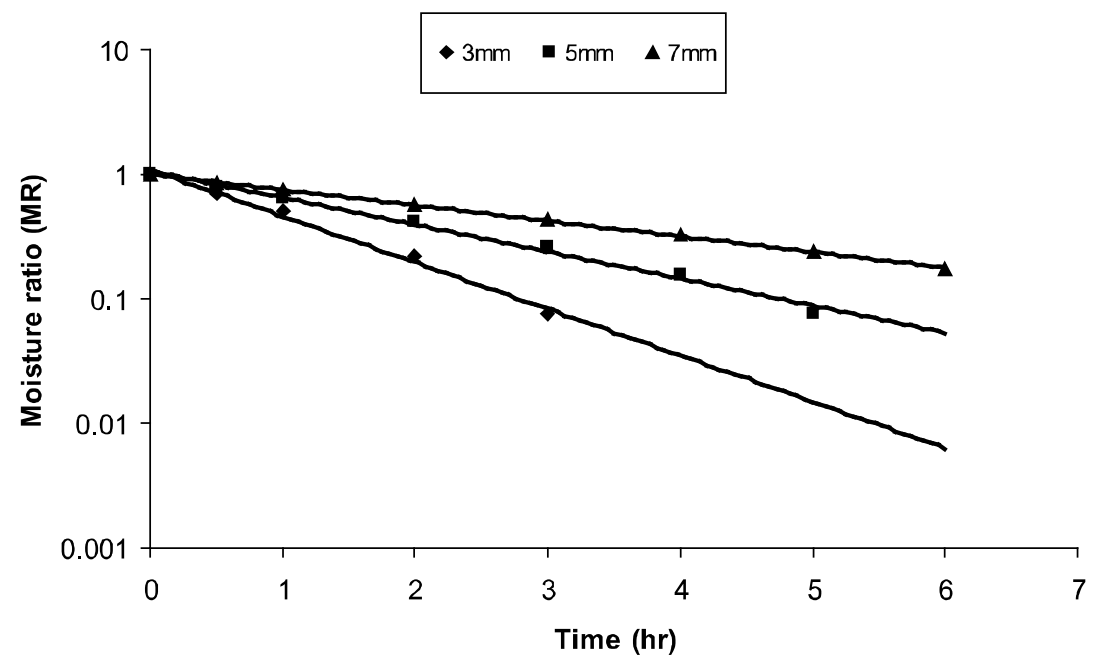

Fig.1 Influence of thickness on drying rate of unblanched onion slice.

In case of blanched onion slices the following regression equation were developed:

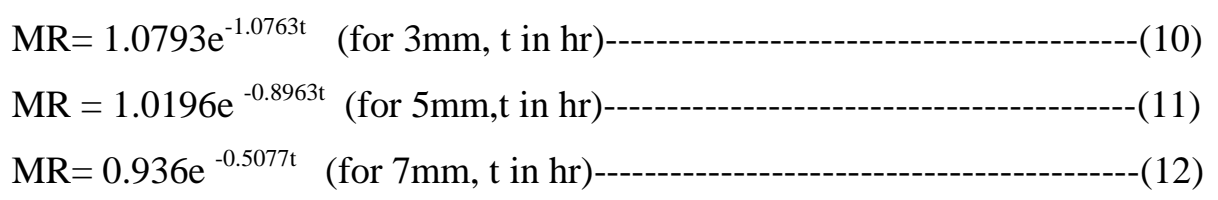

Comparing Fig.2. and Fig. 1 and also with developed equations ( 7 to 9 and 10 to 12) it was clear that for the same thickness, blanched slices gave higher drying rate constant and thus dried faster than unblanched onion slices. It is seen that 3 $\mathrm{mm}$ slice requires least time $(2.21 \mathrm{hr})$, followed by $5 \mathrm{~mm}$ slice $(2.59 \mathrm{hr})$, while 7 $\mathrm{mm}$ thick slice requires the highest drying time $(4.41 \mathrm{hr})$ to dry to $\mathrm{MR}=0.1$. It can be shown that $40-45 \%$ time can be saved by drying 7, 5 and $3 \mathrm{~mm}$ thick slices, indicating increased efficiency in energy utilization for the case of blanched onion. This behavior may be due to the heating effect of the steam used for blanching of onion slices (prior to drying) with changed physical and chemical properties. Ajibola (1987) observed that the longer the blanching time the lower was the moisture content after blanching. Mokanjuola et al (1987) showed that moisture content of onion slices was lower after blanching. Arsdel et al. (1973) observed that blanching prior to dry gives increased rate constant when compared to unblanched product. 


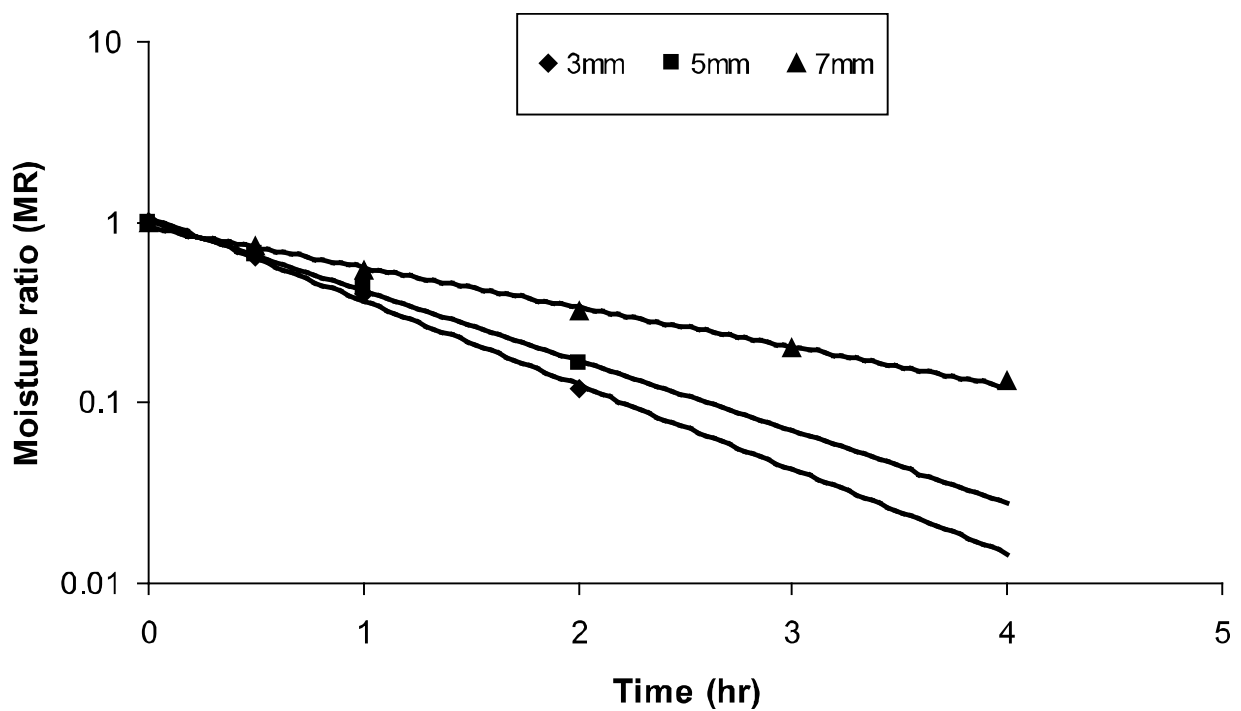

Fig. 2 Influence of thickness on drying rate of blanched onion slice.

The drying rate constants obtained from equation 7 to 9 and 10 to 12 for each sample thickness were plotted (Fig.3) against sample thickness on log-log coordinates as per equation (4) to determine the thickness dependence of rate constants.

The relationship is represented by a power law (regression) equation which follows as;

$\mathrm{m}=3.5806 \mathrm{~L}^{-1.2725}$

$\mathrm{m}=2.9181 \mathrm{~L}^{-0 . .8437}$

Where, $\mathrm{m}=$ drying rate constant $\left(\mathrm{hr}^{-1}\right), \mathrm{L}=$ sample thickness $(\mathrm{mm})$

From equation 13, it is seen that value of index ' $n$ ' of the power low equation is 1.272. This value is quite lower than 2 as predicted by Fick's unsteady state equation (3) indicating that the external resistance to mass transfer was highly significant and internal resistance to mass transfer did not control the drying process under the given conditions. This conditions resulted primarily due to low airflow rate $(<1 \mathrm{~m} / \mathrm{s})$, since similar samples did not indicate the presence of external mass transfer resistance under conditions of high air velocity $(>2 \mathrm{~m} / \mathrm{s})$ as noted by Islam and Flink (1982 b). Islam (2003) found an n value of 1.57 for mechanical drying of indigenous varitey of onion and Hai (2002) found 0.49 for banana using similar air velocity $(0.6 \mathrm{~m} / \mathrm{s})$. Kamruzzaman (2005) dried aroids under similar conditions and found ' $n$ ' value of 1.15. Islam (1980) found an ' $n$ ' value of 1.70 while drying potato using significantly higher airflow rates (2.5 
$\mathrm{m} / \mathrm{s}$ ). The above discrepancy of ' $\mathrm{n}$ ' values is primarily due to airflow rate and thickness range used and indicated the relative importance of external or internal mass transfer resistance. Internal mass transfer resistance is affected by product thickness, structure and composition. Simultaneous heat and mass transfer effects also play an important role in this regard. Islam (1980) while working with potato, showed that by taking into account of the simultaneous heat and mass transfer effect value of ' $n$ ' could be corrected to 2 from 1.7. Alzamora et al. (1978) using significantly high air velocity $(13 \mathrm{~m} / \mathrm{s})$ to greatly reduce external mass transfer resistance, found the dependence of drying rate constant to be somewhat lower than the second power of sample thickness and lower value was attributed to simultaneous heat and mass transfer effects.

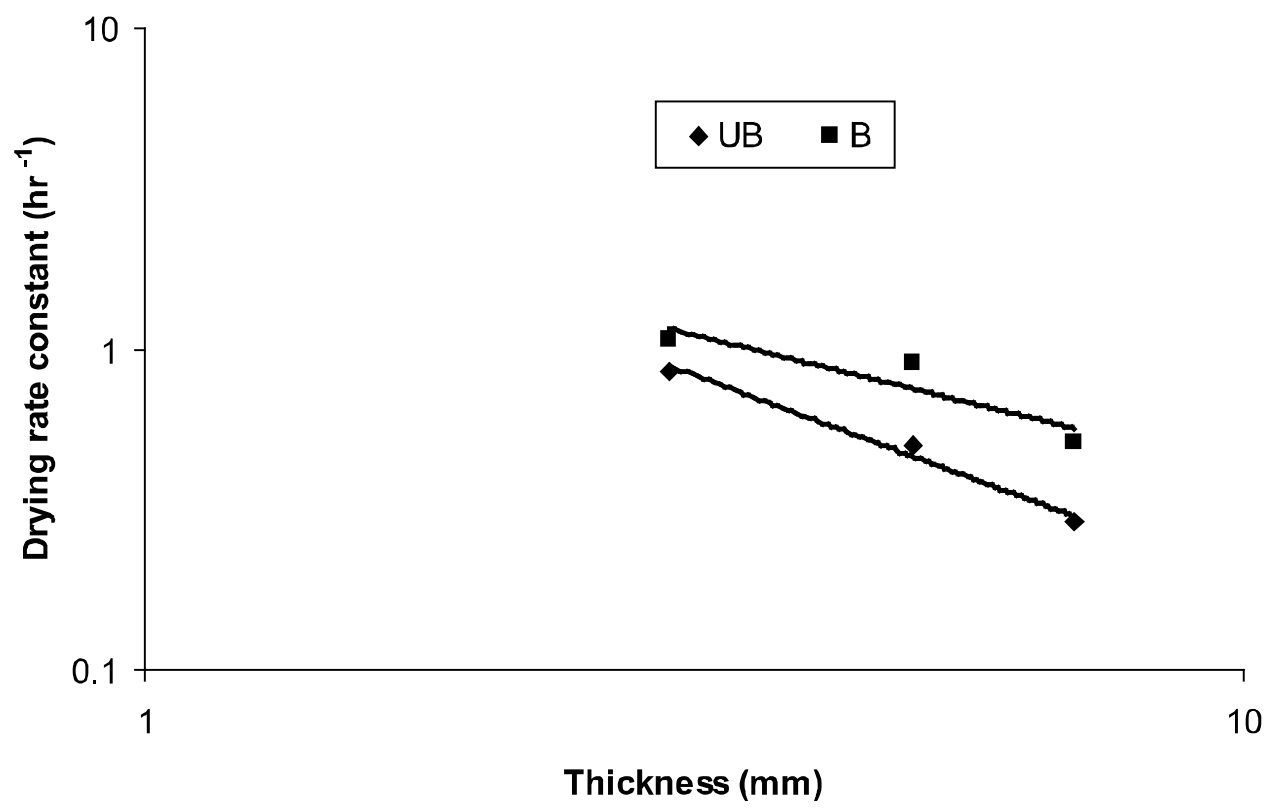

Fig.3 Effect of thickness on drying rate constant of blanched and unblanched onion slice.

From above equation 14, the value of ' $\mathrm{n}$ ' is 0.845 for blanched products whereas for unbalanced products it was found 1.277. Aziz (2001) found different $\mathrm{n}$ value for blanched and unblanched cassava which were 0.776 and 0.79 respectively. The difference in $\mathrm{n}$ values and drying rate constants at a given thickness, between blanched and unblanched samples may be attributed to relative importance of external or internal resistance to heat and mass transfer offered by the samples, undergoing drying. 
Effect of temperature on drying time of unblanched and blanched onion slice

$5 \mathrm{~mm}$ thick onion slices were dried in mechanical drier using three different air dry bulb temperatures $\left(52^{\circ} \mathrm{C}, 60^{\circ} \mathrm{C}\right.$, and $\left.68^{\circ} \mathrm{C}\right)$ to determine the influence of temperature on drying time. The experimental data were analyzed by using equation (3) and plots of moisture ratio versus drying time were made on semi$\log$ co-ordinate and regression lines were drawn (Fig.4). Accordingly, the following equations were developed:

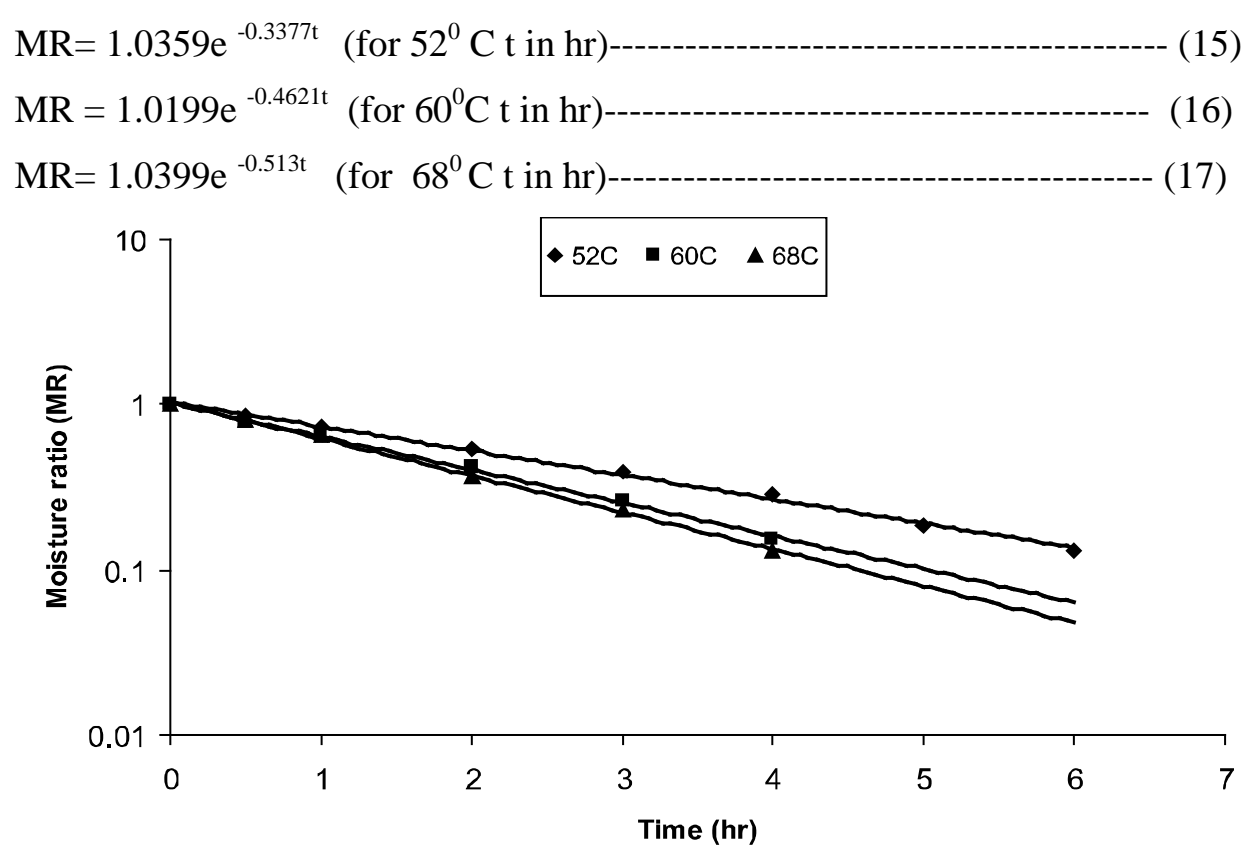

Fig.4 Influence of temperature on drying rate of unblanched onion slice.

From Fig. 4 and the developed equation (15 to 17$)$ it is clearly seen that when temperature is increased, drying rate constant is also increased. The drying time to a specific moisture ratio was decreased with the increase in drying temperature at constant sample thickness. As a result drying rate constant increased with increasing temperature. It was also noticeable that for a specific moisture ratio, the least drying time was achieved at $68^{\circ} \mathrm{C}$, followed by $60^{\circ} \mathrm{C}$, while the highest drying time was required at $52^{\circ} \mathrm{C}$ to dry $5 \mathrm{~mm}$ onion slice.

In case of blanched onion slices the following regression equations were developed:

\begin{tabular}{|c|c|}
\hline $1077 \mathrm{e}^{-0.9832 t}$ & 2 \\
\hline $\mathrm{MR}=1.2125 \mathrm{e}^{-1.099 \mathrm{t}}$ & (for $60^{\circ} \mathrm{Ct}$ in $\mathrm{hr}$ )--- \\
\hline $\mathrm{MR}=1.2709 \mathrm{e}^{-1.1752 \mathrm{t}}$ & (for $68^{0} \mathrm{Ct}$ in $\mathrm{hr}$ )- \\
\hline
\end{tabular}


From the drying rate constant, the diffusion co-effcients were calculated. By plotting diffusion co-efficient $\left(\mathrm{D}_{\mathrm{e}}\right)$ versus inverse absolute temperature $\left(1 / \mathrm{T}_{\mathrm{abs}}\right)$ in a semi-log scale (as per equation 5) a regression line was drawn (Fig.5). The equation of the straight line can be represented as (Fig. 5).

From the slope of the resultant straight line, activation energy $\left(E_{a}\right)$ for diffusion of water was calculated and found to be $5.78 \mathrm{Kcal} / \mathrm{g}$ mole. This finding is in agreements with the results of Islam (2003). He stated that the activation energy $\left(E_{a}\right)$ for diffusion of water for Bangladeshi and Indian onion slices were found to be 5.44 and $6.81 \mathrm{Kcal} / \mathrm{g}$ mole respectively.

$\mathrm{De}=1.8023 \mathrm{e}^{-2909.4 / \mathrm{T}}$

$\mathrm{D}_{\mathrm{e}}=0.0316 \mathrm{e}^{1240.3 / \mathrm{T}} \mathrm{abs}$

Where,

De $=$ Diffusion co - efficient $\left(\mathrm{cm}^{2} / \mathrm{s}\right), \mathrm{T}_{\mathrm{abs}}=$ Absolute temperature ${ }^{0} \mathrm{~K}$

The activation energy was calculated by the same method as described for unblanched slices and the value of activation energy for diffusion of water from blanched slices was found $2.46 \mathrm{Kcal} / \mathrm{g}$-mol (Fig.5). The activation energy for diffusion of water from blanched onion is lower $(2.46 \mathrm{Kcal} / \mathrm{g}-\mathrm{mol})$ than that obtained for unblanched $(5.78 \mathrm{Kcal} / \mathrm{g}-\mathrm{mol}$, table.1) onion slices indicating the effect of blanching on drying. Aziz (2001) found activation energy 11.06 and $13.05 \mathrm{Kcal} / \mathrm{g}-\mathrm{mol}$ for diffusional of water from blanched and unblanched cassava. The differences in activation energy value may be due to changes in structure following blanching.

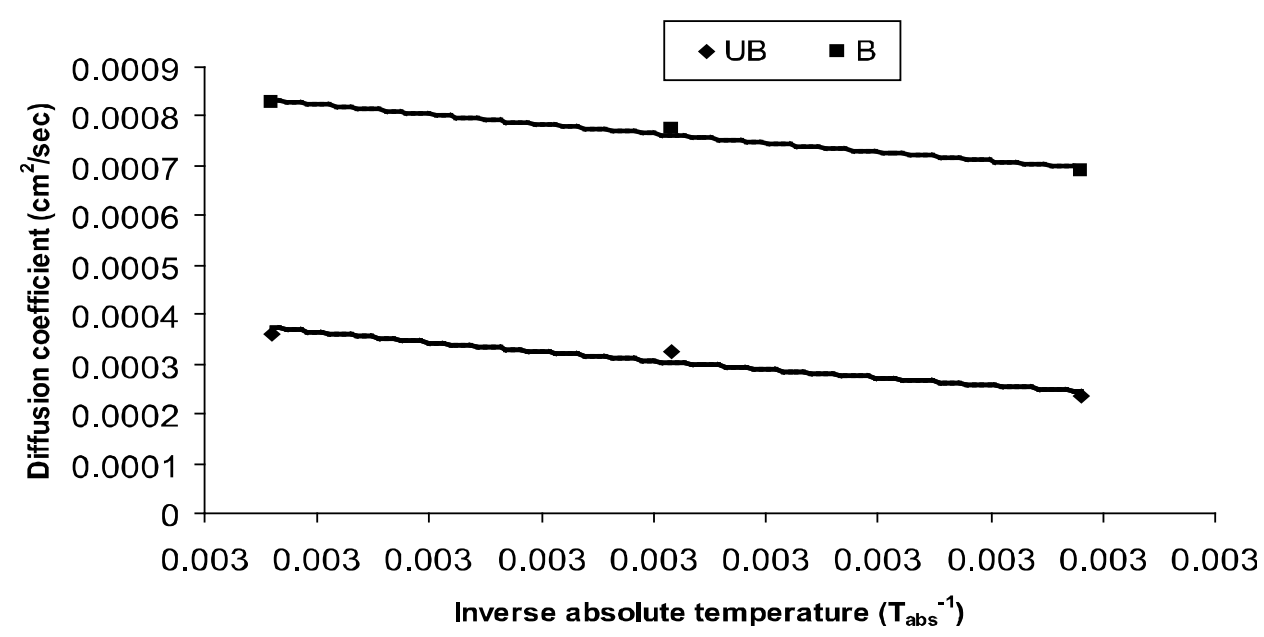

Fig.5 Influence of temperature on diffusion coefficient of blanched and unblanched onion slice 
Table.1 Different drying parameter of mechanical drying system.

\begin{tabular}{c|c|c|c|c|c|c|c}
\hline Product type & $\begin{array}{c}\text { Drying } \\
\text { method }\end{array}$ & $\begin{array}{c}\text { Product } \\
\text { thickness } \\
(\mathrm{mm})\end{array}$ & $\begin{array}{c}\text { Drying } \\
\text { Temp. }(0 \\
\mathrm{C})\end{array}$ & $\begin{array}{c}\text { Slope } \\
(\mathrm{m}) \mathrm{hr}\end{array}$ & $\begin{array}{c}\text { Diffusion } \\
\text { coefficient } \\
\left(\mathrm{cm}^{2} / \mathrm{sec}\right)\end{array}$ & $\begin{array}{c}\text { Value of } \\
\text { exponent } \\
\text { (n value })\end{array}$ & $\begin{array}{c}\text { Activation } \\
\text { energy } \\
\text { (Kcal/ } \\
\text { g-mole })\end{array}$ \\
\hline $\begin{array}{c}\text { Unblanched } \\
\text { summer } \\
\text { onion } \\
\text { (BARI-2) }\end{array}$ & Mechanical & 3 & 60 & 0.8584 & $2.17 \times 10^{-6}$ & 1.277 & - \\
\hline Do & Do & 5 & 52 & 0.3377 & $2.38 \times 10^{-6}$ & - & 5.78 \\
& & & 60 & 0.4621 & $3.25 \times 10^{-6}$ & & \\
\hline Blanched & Do & 3 & 60 & 1.0763 & $2.73 \times 10^{-6}$ & 0.845 & - \\
summer & & 5 & & 0.8963 & $6.31 \times 10^{-6}$ & & \\
\hline onion & & 7 & & 0.5077 & $7.00 \times 10^{-6}$ & & \\
\hline Do & Do & 5 & 52 & 0.9832 & $6.92 \times 10^{-6}$ & - & 2.46 \\
& & & 60 & 1.0990 & $7.73 \times 10^{-6}$ & & \\
\hline
\end{tabular}

\section{Conclusion}

From the above study it appeared that mechanical dryer can be used for commercial production of dehydrated onion. The rate of drying depends on air velocity, temperature, thickness etc. Drying time of onion to a specific moisture ratio (eg. $M R=0.1$ ) increased with increase in sample thickness, while the rate constant has a power law relationship with thickness and the value of index of the equation was quite below 2 indicating presence of significant external resistance to mass transfer and increased airflow resulted in higher drying rate. Diffusion coefficient (calculated from rate constants) follow an Arrhenius type relationship with temperature and the activation value found was higher for unblanched onion than blanched onion (5.78 vs $2.46 \mathrm{Kcal} / \mathrm{g}$-mole). Developed equations based on Fick's $2^{\text {nd }}$ law together with activation energy values could be used for process design and optimization and high quality nutritious product. Thus, large number of skilled and semi-skilled persons would be employed in the related industries.

\section{References:}

Ajibola, O.O., B.J. Abonyi and O. Onayemi. 1987. The effect of some processing variables on the dehydration of pregelled Yam peices. Journal of Food Science and Technology. 25 (3) :117-120. 
Alzamora, S.M., J.Chirife, P. Viollaz and L.M. Vaccarezza. 1978. Heat and mass transfer during air drying of avacado. In: Developments of drying. (Ed.A.S.Majumder). Science press, Princeton, New Jersey, U.S.A. pp. 247-254.

Arsdel, V., M.J. Copley and A.I. Morgan. 1973. Food dehydration. Volume I. AVI publishing company, Inc., Westport, Conn., USA. Pp. 82-160.

Arya, P.S. 2003. Spice crops of India. Kalyani Publishers, Ludhiana- New Delhi. Pp. 276.

Aziz, M. G. 2001. Study on the Kinetics of dehydration of cassava and development of cassava based dried products. M.S. thesis, Department of Food Technology and Rural Industries, BAU, Mymensingh, Bangladesh. pp. 42.

BARI. 2010. Annual report of spices research center of Bangladesh Agricultural Research Institute, Shibgonj, Bogra, Bangladesh.

BBS, 2007. Year Book of Agriculture Statistics of Bangladesh, Bangladesh Bureau of Statistics, Planning Division, Ministry of Planning, Govt. of the People's Republic of Bangladesh.

Brooker, D.B., F.W. Bakker, C.W. and Hall 1974: Drying. The AVI Pub. C. Ine. U.S.A. Pp. 185.

Crank, J. 1975. The mathematics of diffusion. Clarendom Press, Oxford.

Hai, M.A. 2002. Influence of drying and frying parameters on development of shelf stable banana chips. M.S. thesis, Department of Food Technology and Rural Industries, BAU, Mymensingh, Bangladesh.

Heldman, D.R. 1974. Food Process Engineering. The AVI pub. Co. Reprint edition. West port, USA. Pp.237-311.

Islam, M. N. 1980. Use of solar Energy for Development of self-stable Potato Product. Ph.D. Thesis. Royal Veterinary and Agricultural University. Copenhagen. Denmark.

Islam, M. S. 2003. The studies on dehydration of onion and development of onion based products. M.S. thesis, Department of Food Technology and Rural Industries, BAU, Mymensingh, Bangladesh. Pp. 34.

Islam, M.N. and J.M.Flink. 1982 b : I. Dehydration of potato. I. Air and solar drying at low air velocities. J. Food Tech. 17: 373-385.

Kamruzzaman, M. 2005. Development of dehydrated aroids product by using mechanical and indirect solar dryer. M.S. thesis, Department of Food Technology and Rural Industries, BAU, Mymensingh, Bangladesh. Pp. 43.

Kumar, H. S.P., P.K. Nagaraju, K. Radhakrisna and A.S. Bawa. 2004. Effect of dehydration techniques on the quality of onion slices. Journal of Food Science and Technology , Mysore. 41(4):397-400.

Lopez, A., P. Versida and J. Abril. 1995. Influence of dry matter content and drying condition on effective diffusion coefficient of onion. Drying Technology. 13 (8\&9), 2181-2190.

Mokanjuola, G.A., M.T. Ige and O.O. Ajibola. 1987. Preliminary studies on a new technique of cassava mash gelatinization. Journal of Agricultural Engineering Research. Pp 37, 97. 
Sharma, G.P., R.C. Verma and P.B. Pathare 2005. Thin layer infrared radiation drying of onion slices. Journals of Food Engineering. 67(3):361-366.

Telis, V.R.N., R.C.B.D.L Murari and F. Yamashita. 2003. Diffusion coefficients during osmotic dehydration of tomatoes in ternary solution. J. Food Engg. 61(2):253-259.

Yoo, K. S. 1988. Post harvest storage studies on the short day onion, Dissertation Abstracts International 48(6): 15-68. Texas U.S.A. 